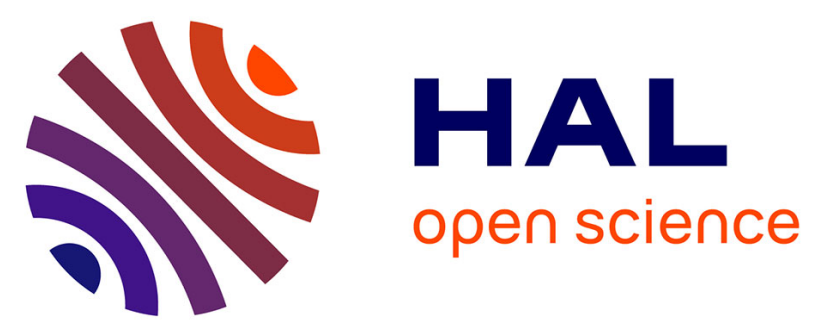

\title{
Mollecarbamates, Molleureas, and Molledihydroisoquinolone, o -Carboxyphenethylamide Metabolites of the Ascidian Didemnum molle Collected in Madagascar
}

Michal Issac, Maurice Aknin, Anne Gauvin-Bialecki, Christopher D. Pond, Louis R. Barrows, Yoel Kashman, Shmuel Carmeli

\section{To cite this version:}

Michal Issac, Maurice Aknin, Anne Gauvin-Bialecki, Christopher D. Pond, Louis R. Barrows, et al.. Mollecarbamates, Molleureas, and Molledihydroisoquinolone, o-Carboxyphenethylamide Metabolites of the Ascidian Didemnum molle Collected in Madagascar. Journal of Natural Products, 2017, 80 (6), pp.1844-1852. 10.1021/acs.jnatprod.7b00123 . hal-01625276

\section{HAL Id: hal-01625276 \\ https: / hal.univ-reunion.fr/hal-01625276}

Submitted on 27 Oct 2017

HAL is a multi-disciplinary open access archive for the deposit and dissemination of scientific research documents, whether they are published or not. The documents may come from teaching and research institutions in France or abroad, or from public or private research centers.
L'archive ouverte pluridisciplinaire HAL, est destinée au dépôt et à la diffusion de documents scientifiques de niveau recherche, publiés ou non, émanant des établissements d'enseignement et de recherche français ou étrangers, des laboratoires publics ou privés. 


\title{
Mollecarbamates, Molleureas, and Molledihydroisoquinolone, o-Carboxyphenethylamide Metabolites of the Ascidian Didemnum molle Collected in Madagascar
}

\author{
Michal Issac, ${ }^{\dagger}$ Maurice Aknin, ${ }^{\ddagger}$ Anne Gauvin-Bialecki, ${ }^{\ddagger}$ Christopher D. Pond, ${ }^{\S}$ Louis R. Barrows, ${ }^{\S}$ \\ Yoel Kashman, ${ }^{\dagger}$ and Shmuel Carmeli*, ${ }^{\dagger}$
}

${ }^{\dagger}$ School of Chemistry, Raymond and Beverly Sackler Faculty of Exact Sciences, Tel-Aviv University, Ramat Aviv Tel-Aviv 69978, Israel

${ }^{\ddagger}$ Laboratoire de Chimie des Substances Naturelles et des Aliments, Faculte des Sciences et Techniques, Universite de la Reunion, 15 Avenue Rene Cassin, B.P 7151, 97715, Saint-Denis, Cedex 9, France

${ }^{\S}$ Department of Pharmacology and Toxicology, School of Medicine, University of Utah, Salt Lake City, Utah 84112, United States

\section{Supporting Information}

\begin{abstract}
The extract of a sample of the tunicate Didemnum molle (MAY13-117) collected in Mayotte afforded eight new metabolites, mollecarbamates A-D (1-4) and molleureas $\mathrm{B}-\mathrm{E}(\mathbf{5}-\mathbf{8})$, along with the two known natural products, $N, N^{\prime}$-diphenylethyl urea (10) and molleurea A (11). Another sample of D. molle (MAD11-BA065) collected in Baie

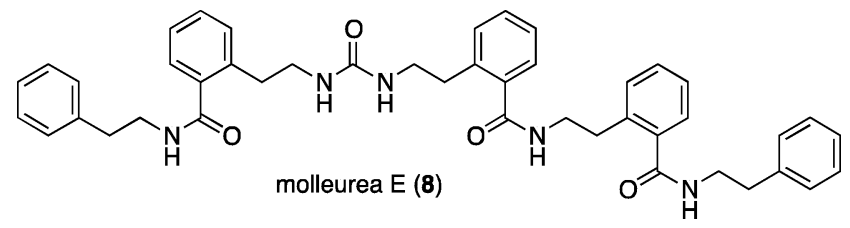
des Assassins, Madagascar, afforded molledihydroisoquinolone (9). Mollecarbamates 1-4 are a family of compounds that possess repeating 0 -carboxyphenethylamide units and a carbamate moiety, while the molleureas 5-8 contain tetra- and penta-repeating carboxyphenethylamide units and a urea bridge in different positions. Molledihydroisoquinolone (9) is a cyclic form of $o$-carboxyphenethylamide. We propose that these unique natural products are most probably produced by an unprecedented biosynthetic pathway that contains a yet unknown chorismate mutase variant. The structures of the compounds were elucidated by interpretation of the data from 1D and 2D NMR, HRESIMS, and MS/MS analyses of the positive ESIMS experiments. Compounds $\mathbf{1 - 8}$ were tested against pathogenic bacteria and in a cytoprotective HIV cell based assay but did not show any significant effects in these assays.
\end{abstract}

\begin{abstract}
A scidians (tunicates), like sponges, have been shown to be a rich source of unique bioactive secondary metabolites with diverse structures derived from different biosynthetic pathways. ${ }^{1}$ The ascidian Didemnum molle is an example of a marine organism that shows high variability of secondary metabolites between collection sites. $^{2-9}$ D. molle is well recognized for the production of heterocycle-containing cyclic hexapeptides, i.e., comoramides, ${ }^{2}$ didmolamides, ${ }^{3}$ mollamides $\mathrm{B}-\mathrm{F},{ }^{4-6}$ keenamide, ${ }^{4}$ and hexamollamide, ${ }^{7}$ and heptapeptides, i.e., mollamide, ${ }^{8}$ cyclodidemnamide, ${ }^{9}$ and mayotamides. ${ }^{2}$ These metabolites have been shown to be biosynthesized in $D$. molle by the symbiotic cyanobacterium Prochloron didemni. ${ }^{5}$ Other metabolites that have been isolated from this ascidian include the sulfated mannopolysaccharide kakelokelose ${ }^{10}$ and more recently the urea derivatives $N, N^{\prime}$-diphenethylurea $(10)^{11}$ and molleurea A (11). ${ }^{6} \mathrm{~N}, N^{\prime}$-Diphenethylurea was initially described from Streptomyces sp. AM-2498 and reported to have an antidepressant effect ${ }^{12}$ and, more recently, enhancement of adipocyte differentiation in 3T3-L1 cells. ${ }^{11}$ Molleurea A presented a mild anti-HIV activity in both an HIV integrase inhibition assay and a cytoprotective cell-based assay. ${ }^{6}$ In the course of our ongoing research aimed at the isolation of potential biomedicines from marine invertebrates, we isolated nine new natural products, mollecarbamates A-D (1-4),
\end{abstract}

molleureas B-E (5-8), and molledihydroisoquinolone (9), alongside the known $N, N^{\prime}$-diphenylethylurea $(\mathbf{1 0})^{11}$ and molleurea A (11) from the extracts of two samples of D. molle. ${ }^{6}$ These metabolites are, as far as we know, the only compounds in the literature that contain ortho-carboxyphenethylamide derivatives in their skeleton. The structure elucidation and the proposed biogenesis of the new compounds are discussed below.

\section{RESULTS AND DISCUSSION}

The extracts of the wet ascidian material (MAY13-117) were separated using a Kupchan solvent partition procedure ${ }^{13}$ and Sephadex LH-20 column chromatography. The semipure compounds were separated by reversed-phase HPLC on a $\mathrm{C}_{18}$ preparative column to afford the eight new natural products mollecarbamates A-D (1-4) and molleureas B-E (5-8) alongside $N, N^{\prime}$-diphenylethyl urea (10) and molleurea A (11). From a second sample of D. molle (MAD11-BA065), molldihydroisoquinolone (9) was isolated by a similar isolation scheme. 


\section{Chart 1}<smiles>COC(=O)NCC[14c]1[14cH]cccc1C(=O)NCCc1ccccc1</smiles>

mollecarbamate A (1)<smiles>COC(=O)NCCc1ccccc1C(=O)NCCc1ccccc1C(=O)NCCc1ccccc1C(=O)NCCc1ccccc1CNC(=O)c1ccccc1CCNC(=O)c1ccccc1CCNC(=O)c1ccccc1CCNC(=O)c1ccccc1CCNC(=O)C1C=CC=CC1CCCCCCC(C)(C)C</smiles><smiles>O=C(NCCc1ccccc1)NCCc1ccccc1C(=O)NCCc1ccccc1C(=O)NCCc1ccccc1</smiles>

molleurea B (5)
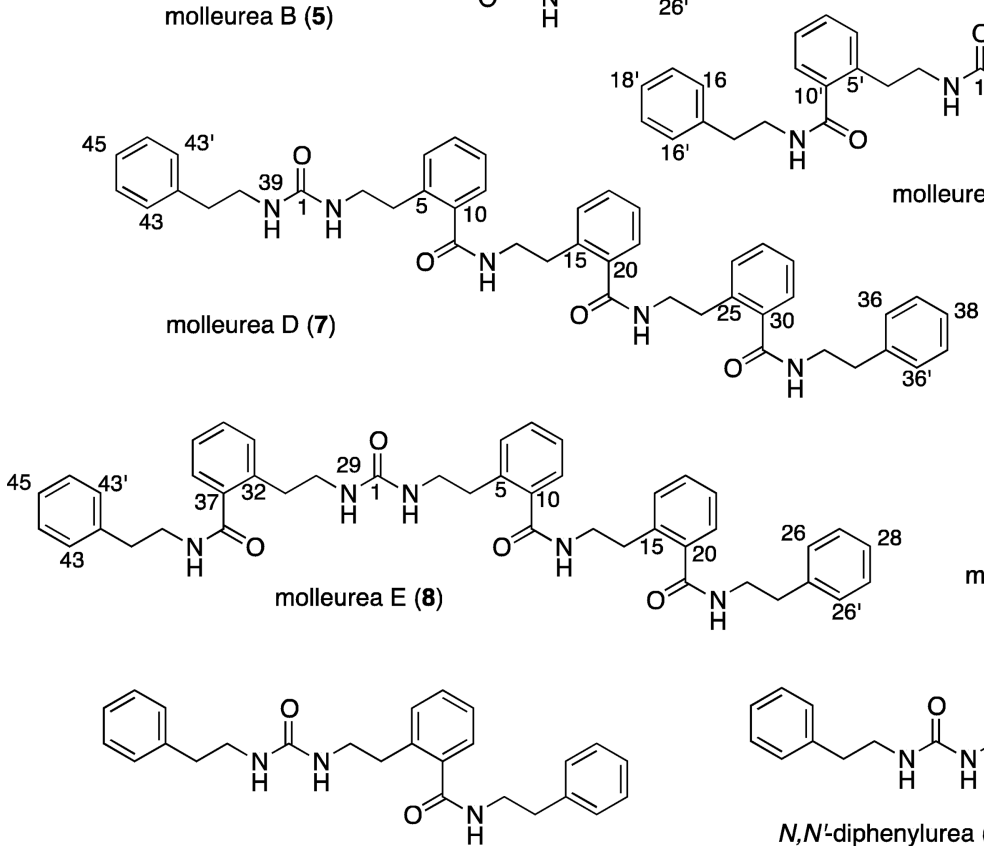

molleurea A (11)<smiles>COC(=O)NCCc1ccccc1C(=O)NCCc1ccccc1C(=O)NCc1ccccc1</smiles><smiles>CCNC(=O)c1ccccc1CCNC(=O)NCCc1ccccc1C(=O)NCCc1ccccc1</smiles><smiles>C1C[GeH2][GeH2]1</smiles><smiles>O=C1NCCc2ccccc21</smiles><smiles>O=C(NCCc1ccccc1)NCCc1ccccc1</smiles>

$N, N$-diphenylurea (10)
Mollecarbamate A (1) was isolated as an amorphous, colorless solid that yielded a positive HRESIMS sodium adduct ion at $m / z 349.1524$, corresponding to the molecular formula $\mathrm{C}_{19} \mathrm{H}_{22} \mathrm{~N}_{2} \mathrm{O}_{3} \mathrm{Na}$ and 10 degrees of unsaturation. The ${ }^{1} \mathrm{H}$ NMR spectrum (in $\mathrm{C}_{6} \mathrm{D}_{6}$, Tables 1 and $\mathrm{S} 1$ in the Supporting Information) of 1 revealed two exchangeable protons (based on the HSQC experiment), four pairs of methylene protons, several aromatic protons, and a methoxy group. The ${ }^{13} \mathrm{C}$ NMR spectrum (Table 1) of $\mathbf{1}$ indicated the presence of mono- and disubstituted aromatic ring systems, one carboxylic carbon (170.4 ppm), and a shielded carbonyl (157.9 ppm). Analysis of the 2D NMR data from the COSY, TOCSY, and HSQC spectra of 1 (Table S1) allowed the assignment of four substructures (Figure 1, bold lines), and HMBC correlations (Figure 1, curved arrows) established two phenethylamine fragments. HMBC correlations, from the protons of the methoxy group resonating at $3.38 \mathrm{ppm}$ and the protons of the methylene resonating at $3.50 \mathrm{ppm}$ to the shielded carbonyl resonating at $157.9 \mathrm{ppm}$, established the structure of a carbamate moiety connected to a short aliphatic chain, as shown in Figure 1. The two fragments were assembled to the full planar structure based on an HMBC correlation between the amide carbonyl resonating at $170.4 \mathrm{ppm}$ and the methylene protons at $3.31 \mathrm{ppm}$. On the basis of this analysis, the structure of mollecarbamate $\mathrm{A}$ was established as $\mathbf{1}$. The structure of 1 was verified by mass analysis of the product ions obtained from a positive mode ESIMS/MS experiment (Figure 2a), presenting characteristic ions that helped with the structure elucidation of the more complex members (3 and 4 ) of this group of metabolites.

The structure elucidation of mollecarbamates B (2), C (3), and $\mathrm{D}$ (4) was accomplished in a similar manner. They differ from 1 in the number of carboxyphenethyl amide units ranging from two to four, respectively. With the growing number of the 
Table 1. NMR Data $\left(\mathrm{C}_{6} \mathrm{D}_{6}\right)$ of Mollecarbamates A-D $(1-4)^{a}$

\begin{tabular}{|c|c|c|c|c|c|c|c|c|}
\hline \multirow[b]{2}{*}{ position } & \multicolumn{2}{|r|}{1} & \multicolumn{2}{|r|}{2} & \multicolumn{2}{|r|}{3} & \multicolumn{2}{|r|}{4} \\
\hline & $\delta_{\mathrm{C}}$, type $^{b}$ & $\overline{\delta_{\mathrm{H}}, \text { mult. }(\mathrm{J} \text { in } \mathrm{Hz})}$ & $\delta_{\mathrm{C}}$, type $^{b}$ & $\overline{\delta_{\mathrm{H}}, \text { mult. }(\mathrm{J} \text { in } \mathrm{Hz})}$ & $\delta_{\mathrm{C}}$, type $^{b}$ & $\delta_{\mathrm{H}}$, mult. $(\mathrm{J}$ in $\mathrm{Hz})$ & $\delta_{\mathrm{C}}$, type $^{b}$ & $\delta_{\mathrm{H}}$, mult. $(J$ in $\mathrm{Hz})$ \\
\hline 1 & 157.9, C & & 158.0, C & & 158.1, C & & 158.5, C & \\
\hline 1-OMe & $51.9, \mathrm{CH}_{3}$ & $3.38, \mathrm{~s}$ & $51.8, \mathrm{CH}_{3}$ & $3.39, \mathrm{~s}$ & 51.6, $\mathrm{CH}_{3}$ & $3.39, \mathrm{~s}$ & 51.6, $\mathrm{CH}_{3}$ & $3.39, \mathrm{~s}$ \\
\hline 2-NH & & 6.34 , brs & & 6.99 , brs & & $7.21, \mathrm{~m}$ & & 7.29 , brs \\
\hline 3 & 44.0, $\mathrm{CH}_{2}$ & $3.50, \mathrm{dt}(10.0,6.5)$ & $44.2, \mathrm{CH}_{2}$ & $3.51, \mathrm{q}(5.5)$ & $44.2, \mathrm{CH}_{2}$ & $3.52, \mathrm{q}(6.0)$ & 43.3, $\mathrm{CH}_{2}$ & $3.55, \mathrm{~m}$ \\
\hline 4 & 33.3, $\mathrm{CH}_{2}$ & $2.69, \mathrm{t}(6.5)$ & 33.0, $\mathrm{CH}_{2}$ & $2.68, \mathrm{~m}$ & $32.9, \mathrm{CH}_{2}$ & $2.69, \mathrm{t}(6.0)$ & $32.7, \mathrm{CH}_{2}$ & $2.71, \mathrm{t}(6.1)$ \\
\hline 5 & 139.4, C & & $139.8, \mathrm{C}$ & & 139.9, C & & 139.7, C & \\
\hline 6 & 131.4, CH & $6.91, \mathrm{~d}(7.5)$ & $131.4, \mathrm{CH}$ & $6.86, \mathrm{~m}$ & $131.2, \mathrm{CH}$ & $6.86, \mathrm{~m}$ & 131.0, $\mathrm{CH}$ & $6.88, \mathrm{~m}$ \\
\hline 7 & $130.8, \mathrm{CH}$ & 6.99, m & $130.7, \mathrm{CH}$ & $6.94, \mathrm{~m}$ & $130.4, \mathrm{CH}$ & $6.94, \mathrm{~m}$ & $130.2, \mathrm{CH}$ & $6.95, \mathrm{~m}$ \\
\hline 8 & $126.8, \mathrm{CH}$ & $6.82, \mathrm{~m}$ & $126.8, \mathrm{CH}$ & $6.88, \mathrm{~m}$ & $126.8, \mathrm{CH}$ & 6.87, m & $126.8, \mathrm{CH}$ & 6.87, m \\
\hline 9 & $127.2, \mathrm{CH}$ & $6.81, \mathrm{~m}$ & $128.0, \mathrm{CH}$ & 7.27, d (7.0) & $128.3, \mathrm{CH}$ & $7.35, \mathrm{~d}(7.0)$ & $127.5, \mathrm{CH}$ & 7.32, d (7.4) \\
\hline 10 & 137.6, C & & 137.7, C & & 137.9, C & & 137.6, C & \\
\hline 11 & $170.4, \mathrm{C}$ & & 171.1, C & & 171.0, C & & 171.2, C & \\
\hline $12-\mathrm{NH}$ & & 4.97, brs & & 8.04 , brs & & 8.70 , brs & & 8.88 , brs \\
\hline 13 & $41.8, \mathrm{CH}_{2}$ & $3.31, \mathrm{dt}(6.5,6.5)$ & 43.1, $\mathrm{CH}_{2}$ & $3.69, \mathrm{dt}(7.0,5.0)$ & 43.4, $\mathrm{CH}_{2}$ & $3.67, \mathrm{~m}$ & 43.1, $\mathrm{CH}_{2}$ & $3.70, \mathrm{~m}$ \\
\hline 14 & 36.4, $\mathrm{CH}_{2}$ & $2.54, \mathrm{t}(6.5)$ & $32.3, \mathrm{CH}_{2}$ & $2.65, \mathrm{~m}$ & 32.0, $\mathrm{CH}_{2}$ & $2.63, \mathrm{t}(6.0)$ & 31.9, $\mathrm{CH}_{2}$ & 2.67, t (5.9) \\
\hline 15 & $139.8, \mathrm{C}$ & & $139.5, \mathrm{C}$ & & 139.7, C & & $139.8, \mathrm{C}$ & \\
\hline $16\left(16^{\prime}\right)$ & 129.7, CH & $6.99, \mathrm{~m}$ & 131.5, $\mathrm{CH}$ & $6.93, \mathrm{~m}$ & $131.4, \mathrm{CH}$ & $6.86 \mathrm{~m}$ & 131.0, $\mathrm{CH}$ & $6.88, \mathrm{~m}$ \\
\hline $17\left(17^{\prime}\right)$ & $129.4, \mathrm{CH}$ & $7.11, \mathrm{~m}$ & 131.1, CH & $7.01, \mathrm{~m}$ & $130.9, \mathrm{CH}$ & $6.95, \mathrm{~m}$ & $129.9, \mathrm{CH}$ & $6.91, \mathrm{~m}$ \\
\hline 18 & $127.3 \mathrm{CH}$ & 7.04, d (7.0) & 127.0, CH & $6.82, \mathrm{t}(7.5)$ & $126.9, \mathrm{CH}$ & $6.91, \mathrm{~m}$ & 126.7, CH & $6.89, \mathrm{~m}$ \\
\hline 19 & & & $127.2, \mathrm{CH}$ & $6.75, \mathrm{~d}(7.5)$ & 127.9, CH & $7.25, \mathrm{~d}(7.2)$ & $127.8, \mathrm{CH}$ & 7.37, d (7.0) \\
\hline 20 & & & 137.4, C & & 137.6, C & & $137.8, \mathrm{C}$ & \\
\hline 21 & & & $170.7, \mathrm{C}$ & & 171.4, C & & 171.2, C & \\
\hline $22-\mathrm{NH}$ & & & & 4.96 , brs & & 8.39, brs & & 8.98 , brs \\
\hline 23 & & & 41.7, $\mathrm{CH}_{2}$ & $3.22, \mathrm{dt}(7.0,6.5)$ & 43.2, $\mathrm{CH}_{2}$ & $3.58, \mathrm{~m}$ & 43.2, $\mathrm{CH}_{2}$ & $3.53, \mathrm{~m}$ \\
\hline 24 & & & $36.2, \mathrm{CH}_{2}$ & $2.45, \mathrm{t}(7.0)$ & 32.1, $\mathrm{CH}_{2}$ & $2.59, \mathrm{t}(6.0)$ & $31.8, \mathrm{CH}_{2}$ & $2.56, \mathrm{~m}$ \\
\hline 25 & & & 139.7, C & & 139.4, C & & 139.6, C & \\
\hline $26\left(26^{\prime}\right)$ & & & $129.6, \mathrm{CH}$ & $6.92, \mathrm{~m}$ & $131.5, \mathrm{CH}$ & $6.85, \mathrm{~m}$ & $131.2, \mathrm{CH}$ & $6.80, \mathrm{~m}$ \\
\hline $27\left(27^{\prime}\right)$ & & & $129.4, \mathrm{CH}$ & $7.09, \mathrm{~m}$ & $131.2, \mathrm{CH}$ & $6.99, \mathrm{~m}$ & $130.2, \mathrm{CH}$ & $6.93, \mathrm{~m}$ \\
\hline 28 & & & 127.4, $\mathrm{CH}$ & 7.04, m & 127.0, $\mathrm{CH}$ & $6.80, \mathrm{t}(6.8)$ & $126.8, \mathrm{CH}$ & $6.88, \mathrm{~m}$ \\
\hline 29 & & & & & 127.1, CH & $6.69, \mathrm{~d}(6.8)$ & $127.7, \mathrm{CH}$ & $7.24, \mathrm{~d}(7.0)$ \\
\hline 30 & & & & & 137.2, C & & 137.2, C & \\
\hline 31 & & & & & $170.8, \mathrm{C}$ & & 171.0, C & \\
\hline $32-\mathrm{NH}$ & & & & & & 4.86 , brs & & 8.55, brs \\
\hline 33 & & & & & 41.7, $\mathrm{CH}_{2}$ & $3.16, \mathrm{q}(6.4)$ & 43.3, $\mathrm{CH}_{2}$ & $3.55, \mathrm{~m}$ \\
\hline 34 & & & & & $36.2, \mathrm{CH}_{2}$ & $2.40, \mathrm{t}(6.4)$ & $31.8, \mathrm{CH}_{2}$ & $2.57, \mathrm{~m}$ \\
\hline 35 & & & & & 139.5, C & & 139.4, C & \\
\hline $36\left(36^{\prime}\right)$ & & & & & 129.6, CH & $6.88, \mathrm{~m}$ & 131.0, $\mathrm{CH}$ & $6.88, \mathrm{~m}$ \\
\hline $37\left(37^{\prime}\right)$ & & & & & $129.8, \mathrm{CH}$ & $7.08, \mathrm{t}(7.4)$ & $130.5, \mathrm{CH}$ & $6.99, \mathrm{~m}$ \\
\hline 38 & & & & & $127.5, \mathrm{CH}$ & 7.04, t (7.4) & $126.7, \mathrm{CH}$ & $6.79, \mathrm{~m}$ \\
\hline 39 & & & & & & & $126.8, \mathrm{CH}$ & $6.68, \mathrm{~d}(7.2)$ \\
\hline 40 & & & & & & & 137.0, C & \\
\hline 41 & & & & & & & 170.6, C & \\
\hline 42-NH & & & & & & & & 4.86 , brs \\
\hline 43 & & & & & & & 41.6, $\mathrm{CH}_{2}$ & $3.16, \mathrm{q}(6.5)$ \\
\hline 44 & & & & & & & $36.2, \mathrm{CH}_{2}$ & $2.40, \mathrm{t}(6.5)$ \\
\hline 45 & & & & & & & 139.3, C & \\
\hline $46,46^{\prime}$ & & & & & & & 129.6, CH & $6.89, \mathrm{~m}$ \\
\hline $47,47^{\prime}$ & & & & & & & $128.9, \mathrm{CH}$ & $7.09, \mathrm{t}(7.2)$ \\
\hline 48 & & & & & & & $126.8, \mathrm{CH}$ & $7.04, \mathrm{~d}(7.2)$ \\
\hline
\end{tabular}

carboxyphenethyl amide units, the structure elucidation became much more complicated and the support of the MS/MS fragmentation data was crucial.

Mollecarbamate B (2) presented an HRESIMS sodium adduct ion at $\mathrm{m} / z 496.2216$ corresponding to the molecular formula $\mathrm{C}_{28} \mathrm{H}_{31} \mathrm{~N}_{3} \mathrm{NaO}_{4}$ and 15 degrees of unsaturation. Its proton NMR data $\left(\mathrm{C}_{6} \mathrm{D}_{6}\right.$, Tables 1 and $\left.\mathrm{S} 2\right)$ were similar to those of 1, revealing additional signals of two pairs of methylene protons $\left(\delta_{\mathrm{H}} 3.69\right.$ and 2.65), an exchangeable proton $\left(\delta_{\mathrm{H}} 8.04\right)$, and aromatic protons $\left(\delta_{\mathrm{H}} 7.30-6.60\right)$. The ${ }^{13} \mathrm{C}$ NMR spectrum of 2 (Table 1 ) revealed nine additional carbon signals to those displayed in the spectrum of 1: two methylene carbons $\left(\delta_{\mathrm{C}} 43.1\right.$ and 32.3$)$, a carboxylic carbon $\left(\delta_{\mathrm{C}} 170.7\right)$, two nonprotonated aromatic carbons $\left(\delta_{\mathrm{C}} 139.5\right.$ and 137.4), and four methine carbons $\left(\delta_{\mathrm{C}} 131.5,131.1,127.2\right.$, and 127.0 $)$. This suggested that mollecarbamate B (2) contains an additional 


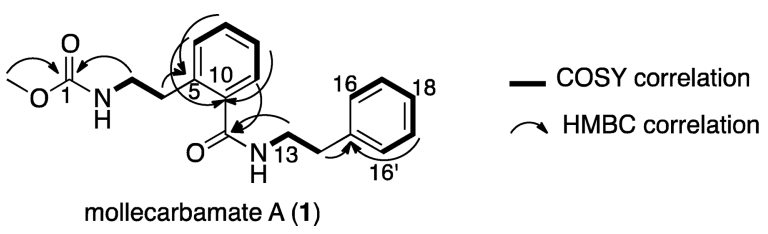

Figure 1. Representative COSY and HMBC correlations that support the structure elucidation of $\mathbf{1}$.

carboxyphenethyl amide unit. This subunit was connected through HMBC correlations to a phenethylamide moiety and to a carboxyphenethylcarbamate moiety similar to those in $\mathbf{1}$. On the basis of these results the structure of mollecarbamate B was established as 2. The MS/MS data (Figure S14) supported the proposed structure.

Mollecarbamate C (3) presented an HRESIMS sodium adduct ion at $m / z 643.2897$, corresponding to the molecular formula $\mathrm{C}_{37} \mathrm{H}_{40} \mathrm{~N}_{4} \mathrm{NaO}_{5}$ and 20 degrees of unsaturation. The ${ }^{1} \mathrm{H}$ and ${ }^{13} \mathrm{C}$ NMR spectra of 3 suggested the presence of four ethylamide groups (Table 1 ) and a carbamate unit (methoxy, $\delta_{\mathrm{H}} 3.39, \delta_{\mathrm{C}} 51.6$; carbonyl, $\delta_{\mathrm{C}} 158.1$; and amide, $\left.\delta_{\mathrm{H}} 7.21\right)$, three carbonyl carbons $\left(\delta_{\mathrm{C}} 171.4,171.0\right.$, and 170.8), and highly crowded aromatic regions. Analysis of the 2D NMR data (COSY, TOCSY, NOESY, HSQC, HMBC, Table S3) revealed that 3 is composed of phenethylamide and three carboxyphenethylamides in a row, terminated with a carbamate unit. The proposed structure was supported by the MS/MS fragment ions at $m / z 589,399,252$, and 105 (Figure S21). Thus, structure 3 was assigned to mollecarbamate C.

Mollecarbamate D (4) presented an HRESIMS sodium adduct ion at $\mathrm{m} / z 790.3579$ corresponding to the molecular formula $\mathrm{C}_{46} \mathrm{H}_{49} \mathrm{~N}_{5} \mathrm{NaO}_{6}$ and 25 degrees of unsaturation. The ${ }^{1} \mathrm{H}$ and ${ }^{13} \mathrm{C}$ NMR spectra of 4 (Table 1) were highly complicated for interpretation because all signals were concentrated in very narrow regions, especially in the aromatic area; however four carbonyl carbons, four ethylamide units, and a carbamate moiety were evident from these spectral data. The structure elucidation was determined in a similar manner to 13 and supported by MS/MS fragment ions at $m / z 736,546$, 399, 252, and 105 (Figure S28), suggesting structure 4 for mollecarbamate $\mathrm{D}$.

Molleurea B (5) was isolated as an amorphous, colorless solid that presented an HRESIMS sodium adduct ion at $\mathrm{m} / z$ 585.2844, corresponding to the molecular formula $\mathrm{C}_{35} \mathrm{H}_{38} \mathrm{~N}_{4} \mathrm{NaO}_{3}$ and 19 degrees of unsaturation. The ${ }^{1} \mathrm{H}$ NMR spectrum (in $\mathrm{C}_{6} \mathrm{D}_{6}$, Tables 2 and $\mathrm{S} 5$ ) revealed eight groups of methylene protons (3.70-2.47 ppm), aromatic protons (7.33-6.77 ppm), and four exchangeable protons $(8.23,5.82,5.13$, and $4.50 \mathrm{ppm})$. Together with the ${ }^{13} \mathrm{C}$ NMR data (Table 2) the presence of two mono- and two disubstituted aromatic ring systems (139.7-126.7 ppm) was suggested. Furthermore, the ${ }^{13} \mathrm{C}$ NMR spectrum revealed two carboxylic carbons (171.7 and $171.0 \mathrm{ppm}$ ) and a shielded carbonyl (159.1 ppm). Analysis of the 2D NMR data from the COSY, TOCSY, and HSQC spectra of molleurea B (Table S5) allowed the assignment of the proton sequence (Figure 3, bold lines) and together with the HMBC correlations (Figure 3, arrows) established two phenethylamine and two carboxyphenethylamine fragments. The four subunits were assembled to the full planar structure based on $\mathrm{HMBC}$ and NOE correlations (Figure 3, dashed lines). An NOE correlation between the two ureido-amide protons resonating at 5.82 and $4.50 \mathrm{ppm}$ allowed connection of fragments A and B. HMBC correlations between the methylene protons at 3.70 and $3.23 \mathrm{ppm}$ and the amide carbonyls resonating at 171.7 and $171.0 \mathrm{ppm}$, respectively, allowed connection of fragments $\mathrm{B}$ to $\mathrm{C}$ and $\mathrm{C}$ to $\mathrm{D}$. The MS/
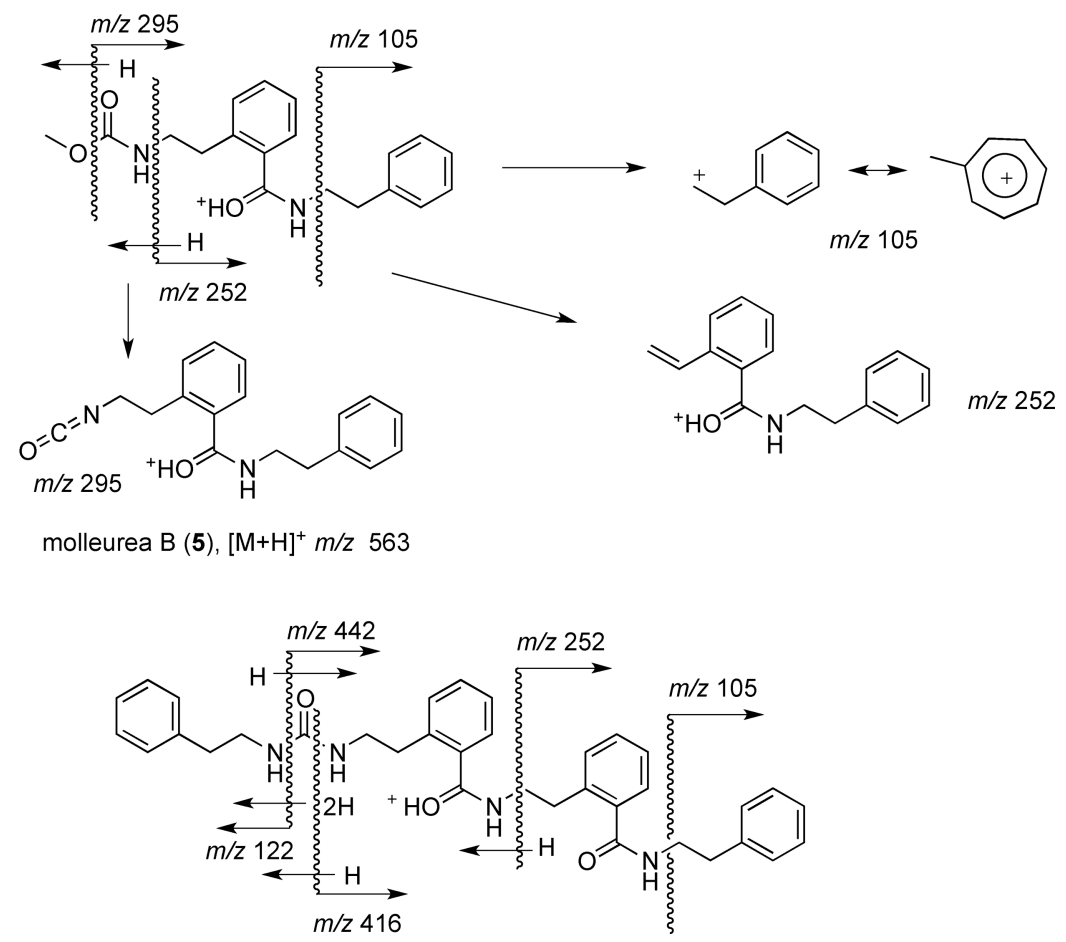

Figure 2. MS/MS fragmentation patterns (a) of mollecarbamate A (1) and (b) of molleurea B (5). 
Table 2. NMR Data $\left(\mathrm{C}_{6} \mathrm{D}_{6}\right)$ of Molleureas B-E $(5-8)^{a}$

\begin{tabular}{|c|c|c|c|c|c|c|c|c|}
\hline \multirow[b]{2}{*}{ position } & \multicolumn{2}{|r|}{5} & \multicolumn{2}{|r|}{6} & \multicolumn{2}{|r|}{7} & \multicolumn{2}{|r|}{8} \\
\hline & $\delta_{\mathrm{C}}$, type $^{b}$ & $\delta_{\mathrm{H}}$, mult. $(J$ in $\mathrm{Hz})$ & $\delta_{\mathrm{C}}$, type $^{b}$ & $\delta_{\mathrm{H}}$, mult. $(J$ in $\mathrm{Hz})$ & $\delta_{\mathrm{C}}$, type $^{b}$ & $\overline{\delta_{\mathrm{H}}, \text { mult. }(J \text { in } \mathrm{Hz})}$ & $\delta_{\mathrm{C}}$, type $^{b}$ & $\delta_{\mathrm{H}}$, mult. $(J$ in $\mathrm{Hz})$ \\
\hline 1 & 159.1, C & & 158.6, C & & 158.7, C & & 159.4, C & \\
\hline 2-NH & & 5.82 , brs & & 5.10, brs & & 6.05 , brs & & 5.26 , brs \\
\hline 3 & $43.5, \mathrm{CH}_{2}$ & $3.46, \mathrm{~m}$ & $42.4, \mathrm{CH}_{2}$ & $3.41, \mathrm{~m}$ & 43.4, $\mathrm{CH}_{2}$ & $3.50, \mathrm{~m}$ & 43.1, $\mathrm{CH}_{2}$ & $3.30, \mathrm{~m}$ \\
\hline 4 & $34.2, \mathrm{CH}_{2}$ & $2.63, \mathrm{t}(7.0)$ & 34.0, $\mathrm{CH}_{2}$ & $2.71, \mathrm{t}(7.0)$ & 33.9, $\mathrm{CH}_{2}$ & $2.67, \mathrm{~m}$ & 34.4, $\mathrm{CH}_{2}$ & $2.59, \mathrm{t}(7.0)$ \\
\hline 5 & 139.7, C & & $138.3, \mathrm{C}$ & & $139.8, \mathrm{C}$ & & 139.1, C & \\
\hline 6 & $131.8, \mathrm{CH}$ & $6.88, \mathrm{dt}(1.0,7.0)$ & 131.0, CH & 6.93 , dd $(7.5,1.5)$ & 131.5, CH & $6.90, \mathrm{~m}$ & 131.3, CH & $6.85, \mathrm{~m}$ \\
\hline 7 & $130.7, \mathrm{CH}$ & $6.98, \mathrm{~m}$ & $129.9, \mathrm{CH}$ & $6.99, \operatorname{td}(7.5,1.5)$ & $130.6, \mathrm{CH}$ & 6.97, m & $130.3, \mathrm{CH}$ & 6.94, m \\
\hline 8 & 127.1, CH & 6.91, m & $126.2, \mathrm{CH}$ & $6.86, \operatorname{td}(7.5,1.5)$ & $127.9, \mathrm{CH}$ & $6.89, \mathrm{~m}$ & $126.5, \mathrm{CH}$ & $6.91, \mathrm{~m}$ \\
\hline 9 & $127.9, \mathrm{CH}$ & $7.33, \mathrm{dd}(7.5,1.5)$ & $127.2, \mathrm{CH}$ & $7.02, \mathrm{~d}(7.5)$ & $127.2, \mathrm{CH}$ & 7.37, d (7.2) & $127.9, \mathrm{CH}$ & 7.32, m \\
\hline 10 & 137.8, C & & 137.7, C & & 137.7, C & & 137.7, C & \\
\hline 11 & 171.7, C & & 170.0, C & & 171.4, C & & $170.9, \mathrm{C}$ & \\
\hline $12-\mathrm{NH}$ & & 8.23 , brs & & 5.52 , brs & & 8.71 , brs & & 8.00 , brs \\
\hline 13 & 43.0, $\mathrm{CH}_{2}$ & $3.70, \mathrm{dt}(7.5,6.0)$ & 41.3, $\mathrm{CH}_{2}$ & $3.45, \mathrm{~m}$ & 43.1, $\mathrm{CH}_{2}$ & 3.68 , brq $(6.5)$ & 42.6, $\mathrm{CH}_{2}$ & $3.73, \mathrm{q}(6.3)$ \\
\hline 14 & $32.4, \mathrm{CH}_{2}$ & $2.70, \mathrm{t}(6.0)$ & 36.0, $\mathrm{CH}_{2}$ & $2.67, \mathrm{t}(7.5)$ & 32.0, $\mathrm{CH}_{2}$ & $2.68, \mathrm{~m}$ & 32.3, $\mathrm{CH}_{2}$ & $2.80, \mathrm{t}(6.3)$ \\
\hline 15 & 139.5, C & & 139.6, C & & 139.6, C & & 139.0, C & \\
\hline $16\left(16^{\prime}\right)$ & 131.6, CH & $6.96, \mathrm{~m}$ & $129.2, \mathrm{CH}$ & $7.07, \mathrm{~m}$ & $131.5, \mathrm{CH}$ & $6.88, \mathrm{~m}$ & $131.3, \mathrm{CH}$ & $7.00, \mathrm{~m}$ \\
\hline $17\left(17^{\prime}\right)$ & $131.4, \mathrm{CH}$ & 7.03, m & $128.1, \mathrm{CH}$ & 7.14, m & 131.0, $\mathrm{CH}$ & $6.99, \mathrm{~m}$ & $130.1, \mathrm{CH}$ & $6.99, \mathrm{~m}$ \\
\hline 18 & $127.4, \mathrm{CH}$ & $6.83, \mathrm{dt}(1.0,7.5)$ & $126.7, \mathrm{CH}$ & $7.06, \mathrm{~m}$ & $127.8, \mathrm{CH}$ & $6.91, \mathrm{~m}$ & $126.8, \mathrm{CH}$ & $6.89, \mathrm{~m}$ \\
\hline 19 & $127.3, \mathrm{CH}$ & $6.77, \mathrm{dd}(7.5,1.0)$ & & & $126.9, \mathrm{CH}$ & $7.29, \mathrm{~d}(7.2)$ & 127.1, CH & $6.85, \mathrm{~m}$ \\
\hline 20 & 137.4, C & & & & 137.5, C & & 137.3, C & \\
\hline 21 & 171.0, C & & & & 171.3, C & & 170.6, C & \\
\hline $22-\mathrm{NH}$ & & 5.13, brs & & & & 8.48 , brs & & $5.41, \mathrm{t}(6.0)$ \\
\hline 23 & $41.8, \mathrm{CH}_{2}$ & $3.23, \mathrm{q}(7.0)$ & & & 43.1, $\mathrm{CH}_{2}$ & 3.59 , brq $(6.5)$ & 41.6, $\mathrm{CH}_{2}$ & $3.30, \mathrm{~m}$ \\
\hline 24 & $36.3, \mathrm{CH}_{2}$ & $2.47, \mathrm{t}(7.0)$ & & & $31.8, \mathrm{CH}_{2}$ & 2.61, m & 36.1, $\mathrm{CH}_{2}$ & $2.54, \mathrm{t}(7.0)$ \\
\hline 25 & 139.7, C & & & & 139.4, C & & 139.6, C & \\
\hline $26\left(26^{\prime}\right)$ & 129.6, CH & 7.04, m & & & 131.3, CH & $6.86, \mathrm{~m}$ & 129.6, CH & 6.97, m \\
\hline $27\left(27^{\prime}\right)$ & $129.4, \mathrm{CH}$ & $7.10, \mathrm{~m}$ & & & 131.2, $\mathrm{CH}$ & 7.01, m & $129.4, \mathrm{CH}$ & $7.11, \mathrm{~m}$ \\
\hline 28 & $126.7, \mathrm{CH}$ & $6.93, \mathrm{t}(6.5)$ & & & $126.5, \mathrm{CH}$ & $6.81, \mathrm{t}(7.2)$ & 127.2, CH & 7.06, m \\
\hline 29/29-NH & & 4.50 , brs & & & $126.4, \mathrm{CH}$ & $6.72, \mathrm{~d}(7.2)$ & & 5.26 , brs \\
\hline 30 & $42.8, \mathrm{CH}_{2}$ & $3.36, \mathrm{q}(6.5)$ & & & 137.3, C & & $42.5, \mathrm{CH}_{2}$ & 3.47, q (6.7) \\
\hline 31 & 37.9, $\mathrm{CH}_{2}$ & $2.61, \mathrm{t}(6.5)$ & & & $170.8, \mathrm{C}$ & & 34.6, $\mathrm{CH}_{2}$ & $2.85, \mathrm{t}(6.7)$ \\
\hline $32 / 32-\mathrm{NH}$ & 141.1, C & & & & & 5.00 , brs & 138.7, C & \\
\hline $33\left(33^{\prime}\right)$ & $129.9, \mathrm{CH}$ & 7.04, m & & & 41.5, $\mathrm{CH}_{2}$ & $3.17, \mathrm{q}(6.8)$ & 131.4, $\mathrm{CH}$ & $6.85, \mathrm{~m}$ \\
\hline $34\left(34^{\prime}\right)$ & 129.2, CH & $7.10, \mathrm{~m}$ & & & $36.0, \mathrm{CH}_{2}$ & $2.40, \mathrm{t}(6.8)$ & $130.9, \mathrm{CH}$ & $7.06, \mathrm{~m}$ \\
\hline 35 & $126.8, \mathrm{CH}$ & $6.93, \mathrm{t}(6.5)$ & & & $139.5, \mathrm{C}$ & & $126.5, \mathrm{CH}$ & $6.89, \mathrm{~m}$ \\
\hline $36\left(36^{\prime}\right)$ & & & & & $129.4, \mathrm{CH}$ & $6.90, \mathrm{~m}$ & $127.4, \mathrm{CH}$ & $7.15, \mathrm{~m}$ \\
\hline $37\left(37^{\prime}\right)$ & & & & & 128.9, $\mathrm{CH}$ & $7.10, \mathrm{~m}$ & 138.6, C & \\
\hline 38 & & & & & 126.9, $\mathrm{CH}$ & $7.03, \mathrm{~m}$ & $170.4, \mathrm{C}$ & \\
\hline 39-NH & & & & & & 4.62 , brs & & 6.00 , brs \\
\hline 40 & & & & & 42.6, $\mathrm{CH}_{2}$ & 3.38 , brq $(5.5)$ & 41.7, $\mathrm{CH}_{2}$ & 3.54, q (6.9) \\
\hline 41 & & & & & 37.6, $\mathrm{CH}_{2}$ & 2.62, m & 36.4, $\mathrm{CH}_{2}$ & $2.77, \mathrm{t}(6.9)$ \\
\hline 42 & & & & & $140.9, \mathrm{C}$ & & 140.1, C & \\
\hline $43,43^{\prime}$ & & & & & 129.7, CH & 7.05, m & $129.5, \mathrm{CH}$ & 6.97, m \\
\hline $44,44^{\prime}$ & & & & & $128.9, \mathrm{CH}$ & 7.10, m & $129.2, \mathrm{CH}$ & $7.12, \mathrm{~m}$ \\
\hline 45 & & & & & $126.9, \mathrm{CH}$ & $7.03, \mathrm{~m}$ & 127.1, CH & 7.06, m \\
\hline
\end{tabular}

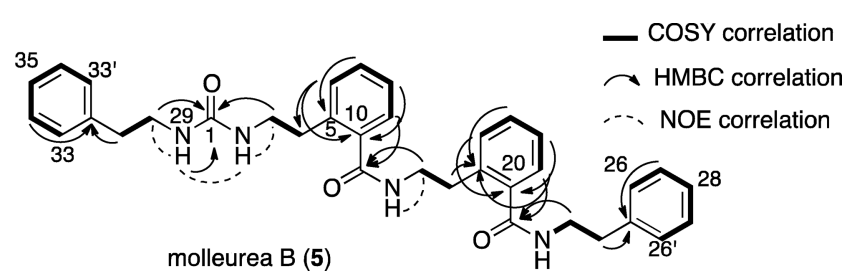

Figure 3. Representative COSY, NOESY, and HMBC correlations that support the structure elucidation of $\mathbf{5}$.

MS fragmentation ions of 5 (Figure $2 b$ ) at $m / z 442,416,252$, 122 , and 105 suggested a phenethylamide linked to two carboxyphenethylamide units in a row and through a urea bridge to a second phenethylamide unit. On the basis of these arguments, the structure of molleurea B was established as $\mathbf{5 .}$

Molleurea C (6) was isolated as an amorphous, colorless solid that yielded an HRESIMS sodium adduct ion at $\mathrm{m} / \mathrm{z}$ 585.2837 corresponding to the molecular formula $\mathrm{C}_{35} \mathrm{H}_{38} \mathrm{~N}_{4} \mathrm{NaO}_{3}$ and 19 degrees of unsaturation. Although 6 yielded an identical molecular formula to that of molleurea $\mathrm{B}$ (5), its ${ }^{1} \mathrm{H}$ and ${ }^{13} \mathrm{C}$ NMR spectra were much simpler than those of 5 , containing half of the signals compared to those of 5 , thus suggesting that 6 had $C_{2}$ symmetry. Its ${ }^{1} \mathrm{H}$ NMR spectrum (Table S6) revealed four signals of aromatic protons indicative 
of a 1,2-disubstituted benzene at 7.02, 6.99, 6.93, and $6.86 \mathrm{ppm}$ and three signals of aromatic protons at 7.14, 7.07, and 7.06 ppm (integration $2: 2: 1$ ) of a monosubstituted benzene ring, two amide protons at 5.52 and $5.10 \mathrm{ppm}$, and signals for four methylenes at $3.45,3.41,2.71$, and $2.67 \mathrm{ppm}$. The ${ }^{13} \mathrm{C} \mathrm{NMR}$ spectrum (Table S6) contained an odd number of signals, one of which, at $158.6 \mathrm{ppm}$, was half the height of the other nonprotonated signals, suggesting its position as the symmetry axis. The structure elucidation of $\mathbf{6}$ was accomplished in a similar manner to that of $\mathbf{5}$, in which two subunits of monoand disubstituted aromatic rings were connected based on an HMBC correlation between the methylene protons at 3.45 ppm and the amide carbonyl resonating at $170.0 \mathrm{ppm}$, and these two identical phenethylamide-carboxyphenethylamide subunits were further connected by an HMBC correlation from the methylene proton signal at $3.41 \mathrm{ppm}$ to the urea carbonyl carbon, at $158.6 \mathrm{ppm}$. The MS/MS fragmentation ions of 6 (Figure S42) at $m / z 295,252,122$, and 105 supported the symmetric structure suggested for molleurea $C$. On the basis of the arguments described above, structure 6 was assigned to molleurea $\mathrm{C}$.

The ${ }^{1} \mathrm{H}$ and ${ }^{13} \mathrm{C}$ NMR spectra of compounds 7 and 8 were highly complicated for interpretation, as all signals were concentrated in very narrow regions of the spectra (especially in the aromatic region) and did not allow unambiguous assignment of all signals. The NMR data of 7 and 8 are presented in Tables 2 and S7 and S8; thus their structure elucidation was secured by interpretation of their fragmentation pattern in the positive ESIMS/MS.

Molleurea D (7) was isolated as an amorphous, colorless solid that yielded an HRESIMS sodium adduct ion at $\mathrm{m} / z$ 732.3531, corresponding to the molecular formula $\mathrm{C}_{44} \mathrm{H}_{47} \mathrm{~N}_{5} \mathrm{NaO}_{4}$ and 24 degrees of unsaturation. The 147 mass unit difference between the molecular ion of 7 and the molecular ion of molleurea C (5) suggested the inclusion of an additional carboxyphenethylamide subunit to the structure of 7 , relative to 5. This was supported by the appearance of five broad amide signals and 10 methylene signals in the ${ }^{1} \mathrm{H}$ NMR spectrum (Table 2) of 7 . The terminal phenethylamide was linked to three carboxyphenethylamide units in a row and through a urea bridge to the second phenethylamide unit through NOESY correlations (Table S7). The structure of 7 was established unequivocally by interpretation of the MS/MS fragmentation ions (Figure S49) at $\mathrm{m} / z$ 589, 563, 544, 399, $269,252,122$, and 105, thus assigning structure 7 to molleurea D.

Molleurea E (8) presented an HRESIMS sodium adduct ion at $m / z 732.3529$, corresponding to the molecular formula $\mathrm{C}_{44} \mathrm{H}_{47} \mathrm{~N}_{5} \mathrm{NaO}_{4}$ and 24 degrees of unsaturation. Although the molecular ion and formula of molleurea $\mathrm{E}(\mathbf{8})$ were identical with those of 7 , and the number of methylene proton and carbon signals in their corresponding NMR spectra was identical, the distribution of the latter NMR signals in their spectra was different (Table 2). The ${ }^{13} \mathrm{C}$ NMR spectrum of $\mathbf{8}$ revealed signals of three amide and one urea carbon (170.9, $170.6,170.4$, and $159.4 \mathrm{ppm}$, respectively) as for 7 , suggesting that 8 differed from molleurea $\mathrm{D}(7)$ in the position of the urea bridge. The terminal phenethylamide was linked to two carboxyphenethylamide units in a row and through a urea bridge to the third carboxyphenethylamide that was connected through its carboxy group to the second phenethylamide unit. The connections of the subunits were deduced from HMBC correlations between the amide carbonyls and the adjacent methylenes and through NOESY correlations between the amide methylenes 3 and 30 from both sides of the urea bridge (3.30 and 3.47 ppm, respectively, Table S8). The structure of 8 was established unequivocally by interpretation of the MS/MS fragmentation ions (Figure S56) at $\mathrm{m} / z$ 442, 416, 269, 252, 122 , and 105 , thus assigning structure 8 to molleurea $\mathrm{E}$.

Molledihydroisoquinolone (9), isolated from a different sample of $D$. molle, presented a positive high-resolution ASAPMS protonated molecule at $m / z$ 148.0774, corresponding to the molecular formula $\mathrm{C}_{9} \mathrm{H}_{10} \mathrm{NO}$ and six degrees of unsaturation. The ${ }^{1} \mathrm{H}$ NMR spectrum of 9 revealed four aromatic protons (7.82-7.29 $\mathrm{ppm})$, one exchangeable proton (7.90 ppm), and two pairs of methylene protons (3.35 and 2.89 ppm). The ${ }^{13} \mathrm{C}$ NMR spectrum revealed the presence of a disubstituted aromatic ring (139.5-127.6 ppm), a conjugated amide carbonyl (164.7 ppm), and two methylene carbons. COSY correlations established two fragments-ethyl amine and an ortho-disubstituted aromatic moiety-while HMBC correlations permitted assembly of the two fragments to the dihydroisoquinolone structure of 9. Dihydroisoquinolone (9) is the simplest cyclic derivative of $o$-carboxyphenethylamine. We examined the extract and fractions obtained from the extract for the presence of compounds $\mathbf{1 - 8}$ and related compounds, by LCMS and NMR, but none of these compounds were found.

Molleurea A, a tris-phenyl urea, isolated from the tunicate D. molle collected from Papua New Guinea, was found to inhibit the HIV virus in a cytoprotective cell based assay with an $\mathrm{IC}_{50}$ value of $60 \mu \mathrm{M}$. ${ }^{6}$ On the basis of this finding, compounds $\mathbf{1 - 8}$ were tested in the cytoprotective HIV assay at concentrations of 5.0 and $0.5 \mu \mathrm{g} / \mathrm{mL}$ and exhibited very weak activity $(48-17 \%$ of protection at $5.0 \mu \mathrm{g} / \mathrm{mL}$, Table S10). Compounds 1-9 were also tested for growth inhibition of the bacteria Pseudomonas aeruginosa, Staphylococcus aureus, and Escherichia coli at a single dose of $50 \mu \mathrm{g} / \mathrm{mL}$ but were all found inactive in these assays.

A literature search surprisingly revealed that apart from molleurea $\mathrm{A}^{6}$ no natural product contains the unique $o$ carboxyphenethylamine subunit in its structure. Furthermore, no biosynthetic route to such a compound is known. The closest known metabolite, $m$-carboxyphenylalanine, is biosynthesized, in certain plants including Nicotina silvestris, ${ }^{14}$ by a unique shikimate pathway, ${ }^{15}$ via the catalysis of isochorismate mutase. We propose here a biogenesis scheme for the molleurea and mollecarbamate precursor $o$-carboxyphenethylamine. The proposed pathway is based on the shikimate pathway and includes a new type of chorismate mutase that converts the putative precursor chorismate isomer 12 into ocarboxyphenethylamine (Scheme 1). The proposed route, in which shikimic acid is converted to 4-enoylpyruvylshikimic acid-5-phosphate (instead of the 3-enoylpyruvylshikimic acid-5phosphate) and further undergoes a 1,2-phosphate elimination, produces intermediate 12 , the 4-enoylpyruvate derivative of chorismic acid. A mutase can transform 12, through a Claisentype rearrangement, into isomeric prephenate 13. Intermediate 13 is proposed to be converted by an aminotransferase to the putative 14, which undergoes 1,4-water elimination by a putative dehydrase to give L-o-carboxyphenylalanine (15), which upon decarboxylation produces $o$-carboxyphenethylamine. Phenethylamine might be produced directly from phenylalanine or through the proposed pathway by decarboxylation of $o$-carboxyphenethylamine, as shown in Scheme 1.

Mollecarbamates 1-4 contain methyl carbamates that might be considered to be isolation artifacts. According to the 
Scheme 1. Biosynthetic Pathways to Phenylalanine and $m$-Carboxyphenylalanine and the Biogenesis of $o$ Carboxyphenethylamine
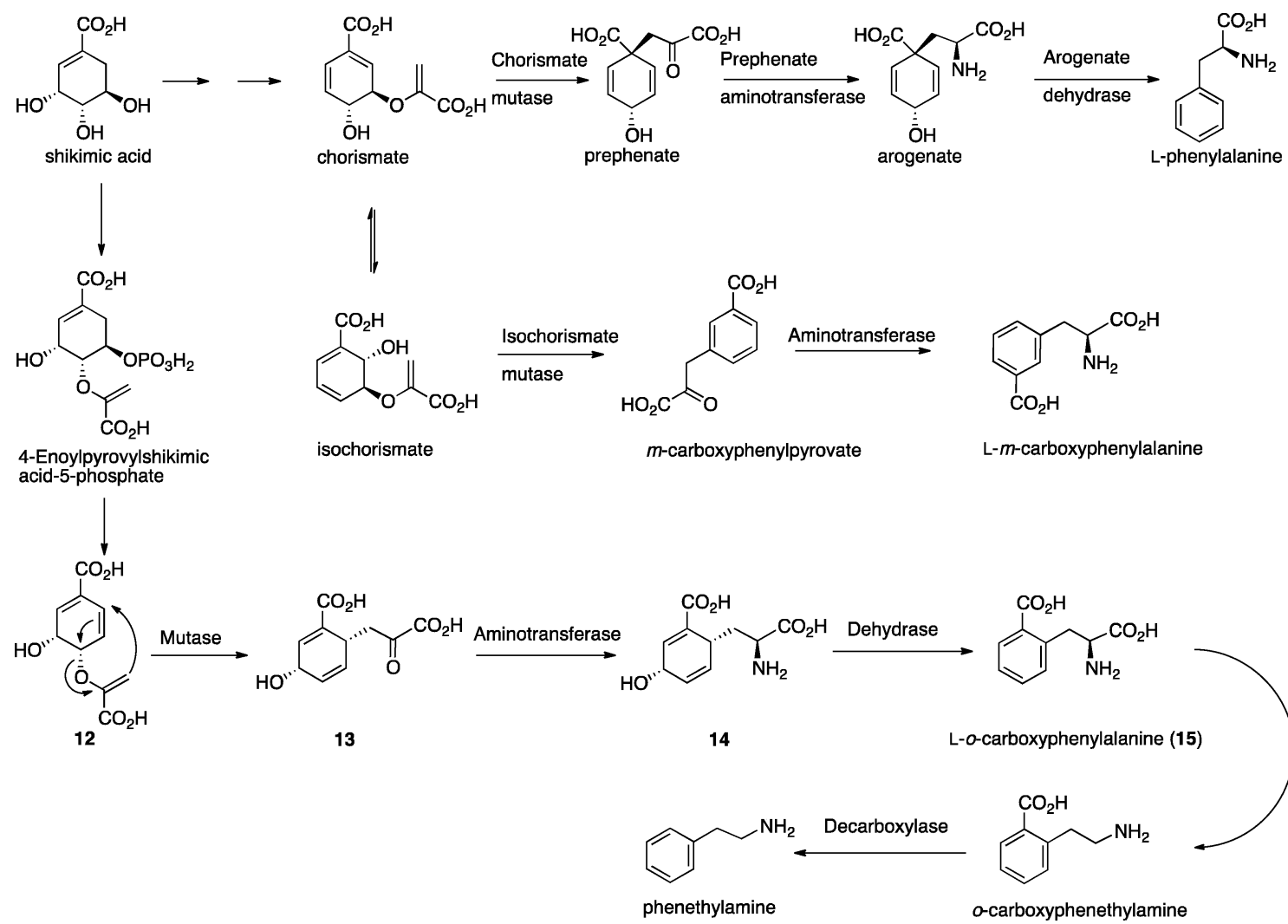

chemistry literature, methyl carbamates can be synthesized from the corresponding primary urea derivatives. A recent publication describes the alcoholysis of urea and alkylurea in excellent yields by alkali-treated zeolite material but at elevated temperature $\left(140-500{ }^{\circ} \mathrm{C}\right) .{ }^{16} \mathrm{~A}$ recently accepted Chinese patent claims that urea and metal oxides can be used under mild reaction conditions for the production of alkylcarbamates, in good yields. ${ }^{17}$ The procedure we utilized for the isolation of mollecarbamates 1-4 used methanol mixtures with dichloromethane and water for extraction and elution of the compounds from the columns but did not expose the compounds to temperatures above $50{ }^{\circ} \mathrm{C}$. HPLC grade silica should not contain metal oxides. Thus, it is not reasonable that 1-4 were produced from the molleureas or the corresponding urea derivatives throughout the isolation procedure. Furthermore, our experience with the urea-bridge-containing anabaenopeptins suggests that substituted urea moieties do not hydrolyze under the usual acidic conditions $\left(6 \mathrm{~N} \mathrm{HCl}, 104{ }^{\circ} \mathrm{C}\right.$, $24 \mathrm{~h}$ ) but rather by treatment with anhydrous hydrazine. ${ }^{18}$ Mollecarbamates 1-4 and molleureaes 5-8 were isolated from a sample of the ascidian D. molle collected in Mayotte (Indian Ocean) alongside $N, N^{\prime}$-diphenylethylurea (10) and molleurea A (11), which had been previously isolated from samples of the same ascidian collected in the Okinawa Prefecture ${ }^{11}$ and in Papua New Guinea (Pacific Ocean), ${ }^{6}$ respectively. The occurrence of the same metabolites in samples of $D$. molle collected in such remote locations suggests that they are indeed produced either by $D$. molle or by one of its common symbiotic microorganisms, Prochloron didemni, ${ }^{5}$ or another yet unrecognized bacterium. The fact that $N, N^{\prime}$-diphenethylurea was initially described from Streptomyces sp. AM-2498 ${ }^{12}$ may suggest that this group of metabolites is produced by a heterotrophic bacterium associated with $D$. molle. Dihydroisoquinolone (9), similar to $N, N^{\prime}$-diphenylethylurea $(\mathbf{1 0})^{11}$ and molleurea A (11), ${ }^{6}$ was isolated as the sole $o$-carboxyphenethylamine derivative from a sample of $D$. molle collected in December 2011 in Baie des Assassins, Madagascar. Although its structure differs from the 10 compounds isolated from the sample collected in May 2013 in Mayotte (an island northwest of Madagascar), we propose that all 11 of these metabolites originate from the same $o$-carboxyphenethylamine building block. The difference in the content of these two samples of D. molle might be a consequence of a difference in the genetics of the animals ${ }^{19}$ or their symbiont ${ }^{5}$ or of seasonality. ${ }^{20}$ This issue may be verified in the future by collection of the ascidians from both locations in the same season and comparison of their genomes and metabolomes. The biogenesis proposed above for the biosynthesis of $o$-carboxyphenethylamine should be proved in the future by genome mining of $D$. molle and its symbionts, isolation of the enzymes involved in the biosynthesis, and mechanistic studies of the processes, a task that is beyond the expertise of our research groups.

\section{EXPERIMENTAL SECTION}

General Experimental Procedures. UV spectra were recorded on an Agilent 8453 spectrophotometer. IR spectra were recorded on a Bruker Tensor 27 FT-IR instrument. NMR spectra were recorded on Bruker Avance and Avance III spectrometers at $500.13 \mathrm{MHz}$ for ${ }^{1} \mathrm{H}$ and $125.76 \mathrm{MHz}$ for ${ }^{13} \mathrm{C}$ (referenced to TMS $\delta=0$ ). DEPT, COSY, gTOCSY, gROESY, gHSQC, gHMQC, and gHMBC spectra were recorded using standard Bruker pulse sequences. High-resolution mass spectra were recorded on a Waters MaldiSynapt instrument (ESI), and LCMS spectra were recorded on a Waters Xevo TQD instrument (ESI). HPLC separations were performed on a Merck Hitachi HPLC 
system (L-6200 Intelligent pump and L-4200 UV-vis detector), a JASCO P4-2080 Plus HPLC system with a multiwavelength detector, and an Agilent 1100 Series HPLC system.

Biological Material. Two samples of the ascidian D. molle were collected in December 2011 (collection number MAD11-BA065; GPS coordinates: $\left.22^{\circ} 13.025 \mathrm{~S}, 43^{\circ} 13.577 \mathrm{E}\right)$ in Baie des Assassins, Madagascar, at a depth of $10-15 \mathrm{~m}$ and in May 2013 (collection number MAY13-117; GPS coordinates: $12^{\circ} 56.388^{\prime} \mathrm{S}, 45^{\circ} 03.247^{\prime} \mathrm{E}$ ) in Mayotte, at a depth of 9-18 m. The identification was made by authors M.A. and A.G.-B., and one voucher specimen of each sample (specimen numbers: MAD11-BA065 and MAY13-117) was deposited at the Laboratoire de Chimie des Substances Naturelles et des Sciences des Aliments (LCSNSA) at the University of Reunion island, France. The samples were frozen immediately after collection and kept at -20 ${ }^{\circ} \mathrm{C}$ until processed.

Isolation of the Natural Products from Didemnum molle. The sample of the tunicate D. molle (MAY13-117, $268 \mathrm{~g}$, dry weight after extraction) was extracted with $1: 1 \mathrm{MeOH} / \mathrm{CH}_{2} \mathrm{Cl}_{2}$ and then with EtOAc $(3 \times 800 \mathrm{~mL}$, each $)$, which afforded 2.60 and $0.65 \mathrm{~g}$ of crude extracts, respectively. The crude extracts were separated using the Kupchan solvent partition procedure: (i) The crude extracts were dissolved in 9:1 $\mathrm{MeOH} / \mathrm{H}_{2} \mathrm{O}$ and partitioned between this solution and petroleum ether (PE). (ii) The $9: 1 \mathrm{MeOH} / \mathrm{H}_{2} \mathrm{O}$ was diluted with water to $7: 3 \mathrm{MeOH} / \mathrm{H}_{2} \mathrm{O}$ and partitioned between this solution and $\mathrm{CH}_{2} \mathrm{Cl}_{2}$. The aqueous $\mathrm{MeOH}$ solution was evaporated to yield $\mathrm{MeOH}$ fractions weighing 356 and $127 \mathrm{mg}$, respectively. The first $\mathrm{MeOH}$ fraction $(356 \mathrm{mg})$ was further separated on a Sephadex LH-20 column eluting with $\mathrm{PE} / \mathrm{MeOH} / \mathrm{CH}_{2} \mathrm{Cl}_{2}(2: 1: 1)$ to afford 15 fractions. Fraction $6(36.0 \mathrm{mg})$ was separated by HPLC on a preparative RP18 column (YMC-Pack ODS-A $250 \times 20 \mathrm{~mm}, 5 \mu \mathrm{m}$, DAD) eluting with $\mathrm{MeOH} / \mathrm{H}_{2} \mathrm{O}(7: 3)$ to afford mollecarbamate C (3) $\left(0.8 \mathrm{mg}, t_{\mathrm{R}}\right.$ $35.6 \mathrm{~min}, 0.12 \%$ yield), molleurea B (5) $\left(1.8 \mathrm{mg}, t_{\mathrm{R}} 57.7 \mathrm{~min}, 0.28 \%\right.$ yield), molleurea $\mathrm{E}(8)\left(2.1 \mathrm{mg}, t_{\mathrm{R}} 67.5 \mathrm{~min}, 0.32 \%\right.$ yield), molleurea $\mathrm{D}$ (7) $\left(1.0 \mathrm{mg}, t_{\mathrm{R}} 79.1 \mathrm{~min}, 0.15 \%\right.$ yield), and molleurea A (11) $(2.2$ $\mathrm{mg}, t_{\mathrm{R}} 48.0 \mathrm{~min}, 0.39 \%$ yield $)$. Combined fractions $7 / 8(20.0 \mathrm{mg})$ were separated by HPLC on a preparative RP-8 column (YMC-Pack C-8 $250 \times 20 \mathrm{~mm}, 5 \mu \mathrm{m}, \mathrm{DAD})$ eluting with $\mathrm{MeOH} / \mathrm{H}_{2} \mathrm{O}(3: 2)$ to afford mollecarbamate A (1) (1.9 mg, $t_{\mathrm{R}} 23.9 \mathrm{~min}, 0.29 \%$ yield), mollecarbamate B (2) (1.3 mg, $t_{\mathrm{R}} 31.7 \mathrm{~min}, 0.20 \%$ yield), molleurea C (6) (1.5 mg, $t_{\mathrm{R}} 55.7 \mathrm{~min}, 0.23 \%$ yield), and $N, N$-diphenethylurea (10) $\left(1.3 \mathrm{mg}, t_{\mathrm{R}} 20.8 \mathrm{~min}, 0.20 \%\right.$ yield). The second $\mathrm{MeOH}$ fraction (127 mg) was further separated on a Sephadex LH-20 column eluted with $\mathrm{PE} / \mathrm{MeOH} / \mathrm{CH}_{2} \mathrm{Cl}_{2}$ (2:1:1) to afford 11 fractions. Fraction 5 (3.0 $\mathrm{mg}$ ) was separated by HPLC on a preparative RP- 8 column (YMCPack C-8 $250 \times 20 \mathrm{~mm}, 5 \mu \mathrm{m}, \mathrm{DAD})$ eluting with $\mathrm{MeOH} / \mathrm{H}_{2} \mathrm{O}(1: 1)$ to afford pure mollecarbamate $\mathrm{D}(4)\left(0.5 \mathrm{mg}, t_{\mathrm{R}} 71.5 \mathrm{~min}, 0.02 \%\right.$ yield).

A sample of the tunicate D. molle (MAD11-BA065, $123 \mathrm{~g}$, dry weight after extraction) was extracted with a mixture of $1: 1 \mathrm{MeOH} /$ $\mathrm{CH}_{2} \mathrm{Cl}_{2}$ and then with EtOAc $(3 \times 500 \mathrm{~mL}$, each $)$ to afford after evaporation the $\mathrm{MeOH} / \mathrm{CH}_{2} \mathrm{Cl}_{2}$ extract $(1.39 \mathrm{~g})$ and the EtOAc extract $(0.74 \mathrm{~g})$. A portion of the $\mathrm{MeOH} / \mathrm{CH}_{2} \mathrm{Cl}_{2}$ extract $(300 \mathrm{mg})$ was separated on a Flash NP-Si column, eluted with $10 \%$ solvent polarity increments from petroleum ether to EtOAc, to afford 13 fractions. Fractions $10-11(13.0 \mathrm{mg})$ were combined and further separated by HPLC on a preparative RP- 8 column (YMC-Pack C-8 $250 \times 20 \mathrm{~mm}, 5 \mu \mathrm{m}, \mathrm{DAD})$ eluting with $\mathrm{CH}_{3} \mathrm{CN} / 0.1 \%$ TFA in $\mathrm{H}_{2} \mathrm{O}$ $(3: 2)$ to afford molledihydroisoquinolone $(9)\left(1.6 \mathrm{mg}, t_{\mathrm{R}} 16.4 \mathrm{~min}\right.$, $0.53 \%$ yield).

Mollecarbamate $A$ (1): amorphous, colorless material; UV $(\mathrm{MeOH}) \lambda_{\max }(\log \varepsilon) 202(4.46) \mathrm{nm}$; IR (ATR Diamond) $\nu_{\max }$ 3296, 1721, 1709, 1679, 1658, 1642, 1563, 1547, 1531, 1366, 1307, 1266, 780, 753, 720, $700 \mathrm{~cm}^{-1}$; NMR data, Tables 1 and S1; HRESIMS $\mathrm{m} / z$ 349.1524 $[\mathrm{M}+\mathrm{Na}]^{+}$(calcd for $\mathrm{C}_{19} \mathrm{H}_{22} \mathrm{~N}_{2} \mathrm{NaO}_{3}$, 349.1528).

Mollecarbamate $B$ (2): amorphous, colorless material; UV $(\mathrm{MeOH}) \lambda_{\max }(\log \varepsilon) 203(4.34) \mathrm{nm}$; IR (ATR Diamond) $\nu_{\max }$ $3307,2923,1637,1597,1538,1445,1414,1363,1315,1266,1194$, 1142, 1086, 919, 830, 751, $700 \mathrm{~cm}^{-1}$; NMR data, Tables 1 and S2;
HRESIMS $m / z$ 496.2216 $[\mathrm{M}+\mathrm{Na}]^{+}$(calcd for $\mathrm{C}_{28} \mathrm{H}_{31} \mathrm{~N}_{3} \mathrm{NaO}_{4}$, 496.2212).

Mollecarbamate C (3): amorphous, colorless material; UV $(\mathrm{MeOH}) \lambda_{\max }(\log \varepsilon) 203(3.90) \mathrm{nm}$; IR (ATR Diamond) $\nu_{\max }$ 3408, 3361, 1631, 1582, 1411, 831, 745, $699 \mathrm{~cm}^{-1}$; NMR data, Tables 1 and S3; HRESIMS $m / z 643.2897[\mathrm{M}+\mathrm{Na}]^{+}$(calcd for $\left.\mathrm{C}_{37} \mathrm{H}_{40} \mathrm{~N}_{4} \mathrm{NaO}_{5}, 643.2896\right)$.

Mollecarbamate $D$ (4): amorphous, colorless material; UV $(\mathrm{MeOH}) \lambda_{\max }(\log \varepsilon) 202$ (4.77) nm; IR (ATR Diamond) $\nu_{\max }$ 3406, 2921, 2851, 1658, 1631, 1581, 1552, 1413, 1366, 752, 720, 699 $\mathrm{cm}^{-1}$; NMR data, Tables 1 and S4; HRESIMS $m / z$ 790.3579 $[\mathrm{M}+$ $\mathrm{Na}]^{+}$(calcd for $\mathrm{C}_{46} \mathrm{H}_{49} \mathrm{~N}_{5} \mathrm{NaO}_{6}, 790.3581$ ).

Molleurea $B$ (5): amorphous, colorless material; $\mathrm{UV}(\mathrm{MeOH}) \lambda_{\max }$ $(\log \varepsilon) 201(3.77) \mathrm{nm}$; IR (ATR Diamond) $\nu_{\max } 3306,3065,3026$, 2927, 2872, 1633, 1598, 1549, 1406, 1363, 1315, 1196, 1159, 1029, 829, 748, $699 \mathrm{~cm}^{-1}$; NMR data, Tables 2 and S5; HRESIMS $\mathrm{m} / z$ $585.2844[\mathrm{M}+\mathrm{Na}]^{+}$(calcd for $\left.\mathrm{C}_{35} \mathrm{H}_{38} \mathrm{~N}_{3} \mathrm{NaO}_{4}, 585.2842\right)$.

Molleurea C (6): amorphous, colorless material; UV (MeOH) $\lambda_{\max }$ $(\log \varepsilon) 203$ (4.34) nm IR (ATR Diamond) $\nu_{\max } 3372,3026,2927$, 2873, 1635, 1598, 1551, 1408, 1366, 1317, 1196, 1159, 1085, 1051, 1030, 829, 750, $700 \mathrm{~cm}^{-1}$; NMR data, Tables 2 and S6; HRESIMS m/ $z 585.2837[\mathrm{M}+\mathrm{Na}]^{+}$(calcd for $\mathrm{C}_{35} \mathrm{H}_{38} \mathrm{~N}_{3} \mathrm{NaO}_{4}, 585.2842$ ).

Molleurea D (7): amorphous, colorless material; UV $(\mathrm{MeOH}) \lambda_{\max }$ $(\log \varepsilon) 203(3.94) \mathrm{nm}$; IR (ATR Diamond) $\nu_{\max } 3405,1659,1631$, 1581, 1411, 1392, 829, 749, $703 \mathrm{~cm}^{-1}$; NMR data, Tables 2 and S7; HRESIMS $m / z 732.3525[\mathrm{M}+\mathrm{Na}]^{+}$(calcd for $\mathrm{C}_{44} \mathrm{H}_{47} \mathrm{~N}_{5} \mathrm{NaO}_{4}$, 732.3531).

Molleurea $E$ (8): amorphous, colorless material; UV $(\mathrm{MeOH}) \lambda_{\max }$ $(\log \varepsilon) 203(4.53) \mathrm{nm}$; IR (ATR Diamond) $\nu_{\max }$ 3296, 3064, 2959, 2922, 2852, 1640,1599, 1548, 1537, 1366, 1315, 1260, 1086, 1030, 789, 751, $701 \mathrm{~cm}^{-1}$; NMR data, Tables 2 and S8; HRESIMS $\mathrm{m} / z$ $732.3529[\mathrm{M}+\mathrm{Na}]^{+}$, calcd for $\mathrm{C}_{44} \mathrm{H}_{47} \mathrm{~N}_{5} \mathrm{NaO}_{4}, 732.3526$ ).

Molledihydroisoquinolone (9): amorphous, colorless material; UV $(\mathrm{MeOH}) \lambda_{\max }(\log \varepsilon) 203(3.79), 232(3.20) \mathrm{nm}$; IR (ATR Diamond) $\nu_{\max } 3401,2271,2264,2139,1683,1292,1206,1155,1043,1019,807$, $722,699 \mathrm{~cm}^{-1}$; ${ }^{1} \mathrm{H}$ NMR (500 MHz, DMSO- $\left.d_{6}\right) \delta 7.90(1 \mathrm{H}, \mathrm{brs}$, $\mathrm{NH}), 7.82(1 \mathrm{H}, \mathrm{brd}, J=7.5 \mathrm{~Hz}, \mathrm{H}-3), 7.45(1 \mathrm{H}, \mathrm{td}, J=7.5,1.3 \mathrm{~Hz}, \mathrm{H}-$ 5), $7.33(1 \mathrm{H}$, brt, $J=7.5 \mathrm{~Hz}, \mathrm{H}-4), 7.29(1 \mathrm{H}, \mathrm{brd}, J=7.5 \mathrm{~Hz}, \mathrm{H}-6)$, $3.35\left(2 \mathrm{H}, \mathrm{td}, J=6.5,3.0 \mathrm{~Hz}, \mathrm{H}_{2}-9\right), 2.89\left(2 \mathrm{H}, \mathrm{t}, J=6.5 \mathrm{~Hz}, \mathrm{H}_{2}-8\right) ;{ }^{13} \mathrm{C}$ NMR (125 MHz, DMSO-d $\left.d_{6}\right) \delta 164.7$ (C-1), 139.5 (C-7), 131.9 (C-5), 129.7 (C-2), 127.7 (C-6), 127.3 (C-3), 126.9 (C-4), 39.8 (C-9), 28.0 (C-8); 2D NMR data, Table S9; HRASAPMS $m / z$ 148.0774 $[\mathrm{M}+$ $\mathrm{H}]^{+}$(calcd for $\mathrm{C}_{9} \mathrm{H}_{10} \mathrm{NO}, 148.0762$ ).

Cytoprotective HIV Cell-Based Assay. ${ }^{21}$ Briefly, 1A2 cells (a subclone of CEM-SS TART cells that are more prone to apoptosis upon HIV infection) were cultured in RPMI/20\% fetal bovine serum and plated in 96-well plates. The assay utilized controls that included cells without HIV, cells infected with HIV, and cells infected with HIV and treated with AZT at a final concentration of $50 \mu \mathrm{g} / \mathrm{mL}$ or test compounds. Uninfected control cells and HIV-exposed cells were allowed to incubate for $96 \mathrm{~h}$ at $37{ }^{\circ} \mathrm{C}$ in $5 \% \mathrm{CO}_{2}$. Cell viability was then assessed with a standard MTT assay. ${ }^{22}$ On each assay plate, each condition was performed in triplicate, and $p$-values were determined between groups to gauge the performance of the assay. For a valid assay, HIV growth had to be less than 50\% of controls; AZT rescue needed to be at least $50 \%$ above HIV killing, and a test compound was considered active if it performed at $70 \%$ of the AZT value.

Bacterial Growth Inhibition Assay. ${ }^{23}$ The bacterial strains utilized in this study, P. aeruginosa ATCC 47085, E. coli ATCC 25922, and S. aureus ATCC 29213, were purchased from the American Type Culture Collection (ATCC). P. aeruginosa was grown in cationadjusted Mueller-Hinton broth (Sigma), while E. coli and S. aureus were grown in LB (Lennox). Starter cultures were incubated for $24 \mathrm{~h}$ $\left(37{ }^{\circ} \mathrm{C}, 5 \% \mathrm{CO}_{2}\right.$, aerobic conditions) and then diluted in fresh medium to obtain an optical density of 0.004 (OD600, Evolution 60, Thermo Scientific). All strains were tested using a single concentration of $50 \mu \mathrm{g} / \mathrm{mL}$ in 96-well flat-bottom plates (Corning). After $24 \mathrm{~h}$ of incubation, MTT $\left(25 \mu \mathrm{L}\right.$ of a $1 \mathrm{mg} / \mathrm{mL}$ solution in $\left.\mathrm{H}_{2} \mathrm{O}\right)$ was added to each well followed by additional incubation at $37^{\circ} \mathrm{C}$ for $1 \mathrm{~h}$. Results 
were obtained from two independent experiments, and each experiment was performed in triplicate.

\section{ASSOCIATED CONTENT}

\section{S Supporting Information}

The Supporting Information is available free of charge on the ACS Publications website at DOI: 10.1021/acs.jnatprod.7b00123.

Spectroscopic data including 1D and 2D NMR spectra, complete tabulated 2D NMR data, HRMS data, and MS/ MS spectra of compounds 1-9 (PDF)

\section{AUTHOR INFORMATION}

\section{Corresponding Author}

*Tel (S. Carmeli): +972-3-6408550. Fax: +972-3-6409293. Email: carmeli@post.tau.ac.il.

\section{ORCID}

Anne Gauvin-Bialecki: 0000-0001-5188-0704

Shmuel Carmeli: 0000-0002-9641-9943

\section{Notes}

The authors declare no competing financial interest.

\section{ACKNOWLEDGMENTS}

The present research was supported in part by a Tel Aviv University internal grant (S.C. and Y.K.). M.A. and A.G.-B. gratefully acknowledge financial support from the European Commission and the Regional Council of Reunion Island: BIOMOL-TCN program (Activités Thérapeutiques, Cosmétologiques et Nutraceutiques de Molécules Issues de la Biodiversité Terrestre, Marine et Microbienne de la Zone Sud-Ouest de l'Océan Indien), ERDF (European Regional Development Fund, grant number 2012-32698), the POMARE program (Polynesian, Mayotte's, Reunion's marine benthic invertebrates: interactions and chemodiversity evaluation for a sustainable use), and NETBIOME (Networking tropical and subtropical biodiversity research in outermost regions and territories of Europe in support of sustainable development, grant numbers ANR 11-EBIM-0006 and DGADD/PE/2012/ 0587). The authors express their gratitude to $M$. E. Remanevy for assistance in sponge collection; Y. Abudi for technical assistance; and N. Tal, the Mass Spectrometry Facility of the School of Chemistry, Tel Aviv University, for the measurements of the mass spectra. M.I. acknowledges the Ph.D. Fellowship from the School of Chemistry of Tel Aviv University.

\section{REFERENCES}

(1) Blunt, J. W.; Copp, B. R.; Keyzers, R. A.; Munro, M. H. G.; Prinsep, M. R. Nat. Prod. Rep. 2016, 33, 382-431.

(2) Rudi, A.; Aknin, M.; Gaydou, E. M.; Kashman, Y. Tetrahedron 1998, 54, 13203-13210.

(3) Rudi, A.; Chill, L.; Aknin, M.; Kashman, Y. J. Nat. Prod. 2003, 66, 575-577.

(4) Donia, M. S.; Wang, B.; Dunbar, D. C.; Desai, P. V.; Patny, A.; Avery, M.; Hamann, M. T. J. Nat. Prod. 2008, 71, 941-945.

(5) Donia, M. S.; Fricke, W. F.; Ravel, J.; Schmidt, E. W. PLoS One 2011, 6, e17897.

(6) Lu, Z.; Harper, M. K.; Pond, C. D.; Barrows, L. R.; Ireland, C. M.; Van Wagoner, R. M. J. Nat. Prod. 2012, 75, 1436-1440.

(7) Teruya, T.; Sasaki, H.; Suenaga, K. Tetrahedron Lett. 2008, 49, 5297-5299.

(8) Carroll, A. R.; Bowden, B. F.; Coll, J. C.; Hockless, D. C. R.; Skelton, B. W.; White, A. H. Aust. J. Chem. 1994, 47, 61-69.
(9) Toske, S. G.; Fenical, W. Tetrahedron Lett. 1995, 36, 8355-8358.

(10) Riccio, R.; Kinnel, R. B.; Bifulco, G.; Scheuer, P. J. Tetrahedron Lett. 1996, 37, 1979-1982.

(11) Choi, S.-S.; Cha, B.-Y.; Kagami, I.; Lee, Y.-S.; Sasaki, H.; Suenaga, K.; Teruya, T.; Yonezawa, T.; Nagai, K.; Woo, J.-T. J. Antibiot. 2011, 64, 277-280.

(12) Iwai, Y.; Hirano, A.; Awaya, J.; Matsuo, S.; Omura, S. J. Antibiot. 1978, 31, 375-376.

(13) Kupchan, S. M.; Stevens, K. L.; Rohlfing, E. A.; Sickles, B. R.; Senden, A. T.; Miller, R. W.; Bryan, R. F. J. J. Org. Chem. 1978, 43, 586-590.

(14) Zamir, L. O.; Nikolakakis, A.; Bonner, C. A.; Jensen, R. A. Bioorg. Med. Chem. Lett. 1993, 3, 1441-1446.

(15) Thompson, J. F.; Morris, C. J.; Asen, S.; Irreverre, F. J. Biol. Chem. 1961, 236, 1183-1185.

(16) Sun, Q.; Niu, R.; Wang, H.; Lu, B.; Zhao, J.; Cai, Q. Microporous Mesoporous Mater. 2017, 248, 108-114.

(17) Deng, Y.; Wang, L.; Wang, P.; Shang, J.; He, Y.; Lu, L. CN Patent 103172538,A, 2013.

(18) Akabori, S.; Ohno, K.; Narita, K. Bull. Chem. Soc. Jpn. 1952, 25, 214-218.

(19) Hirabayashi, S.; Kasai, F.; Watanabe, M. M.; Hirose, E. Hydrobiologia 2006, 571, 419-422.

(20) Fukuda, T.; Hirose, E. Pac. Sci. 2008, 62, 309-316.

(21) Kiser, R.; Makovsky, S.; Terpening, S. J.; Laing, N.; Clanton, D. J. J. Virol. Methods 1996, 58, 99-109.

(22) Mosmann, T. J. Immunol. Methods 1983, 65, 55-63.

(23) Herzog, I. M.; Louzoun Zada, S.; Fridman, M. J. Med. Chem. 2016, 59, 8008-8018. 